\title{
Editor's Acknowledgements
}

The editor would like to thank the following persons for having served as referees for articles during 1991:

\author{
Philippe Barbaud \\ Elizabeth Cowper \\ Ian Dale \\ André Lapierre \\ Ann Laubstein \\ Paul Laurendeau \\ Monique Lefebvre \\ John Lumsden \\ Diane Massam \\ Raymond Mugeon \\ Keren Rice \\ Ian Roberts \\ Michael Rochemont \\ Ron Smyth \\ Jan van Voorst
}




\title{
Association canadienne de linguistique Canadian Linguistic Association
}

\author{
Présidente/President \\ Marie-Thérèse Vinet, Université de Sherbrooke (1990-1992) \\ Vice-Présidente/Vice President \\ Sandra Clarke, Memorial University of Newfoundland (1990-1992) \\ Président du Comité des candidatures/Nominating Committee Chair \\ Marie Surridge, Queen's University (1990-1992) \\ Présidente du Comité de programme/Programme Committee Chair \\ Sheila Embleton, York University (1990-1991) \\ Secrétaire-Trésorier/Secretary-Treasurer \\ Parth Bhatt, University of Toronto (1989-1994) \\ Rédacteur/Editor \\ William Cowan, Carleton University (1988-1993) \\ Membres adjoints/Members at large \\ Denis Bouchard, Université du Québec à Montréal (1990-1993) \\ Michael Dobrovolsky, University of Calgary (1990-1993)
}

Le but principal de l'Association canadienne de linguistique est de promouvoir l'étude de la linguistique au Canada. La cotisation, qui donne droit à l'abonnement à la Revue canadienne de linguistique et au Bulletin de l'Association canadienne de linguistique, ainsi qu'à la soumission de communications au congrès annuel, est de $40 \$$ par année pour les membres ordinaires et de $12 \$$ pour les étudiant(e)s qui peuvent faire la preuve de leur statut. On envoie la cotisation au Secrétaire-Trésorier: Parth Bhatt, Experimental Phonetics Lab, New College, University of Toronto, Toronto, Ontario M5S 1A1; (416) 599-0973; courier électronique: EXPHONLA@UTOREPAS.CA; fax (416) 978-9870. Les annonces pour le Bulletin sont à adresser au Secrétaire-Trésorier. La publication de cette revue est rendue possible par les subventions du Conseil de recherches en sciences humaines du Canada.

The principal aim of the Canadian Linguistic Association is to promote the study of linguistics in Canada. Membership fees, which include a subscription to the Canadian Journal of Linguistics and the Bulletin of the Canadian Linguistic Association, as well as the right to give papers at the Annual Meeting, are $\$ 40$ a year for regular members, and $\$ 12$ for student members with proof of student status. Fees should be paid to the Secretary-Treasurer: Parth Bhatt, Experimental Phonetics Lab, New College, University of Toronto, Toronto, Ontario M5S 1A1; (416) 599-0973; e-mail: EXPHONLA@UTOREPAS.CA; fax (416) 978-9870. Announcements for the Bulletin should be sent to the Secretary-Treasurer. Publication of this journal is made possible by grants from the Social Sciences and Humanities Research Council of Canada. 


\section{CONTENTS/SOMMAIRE}

Satomi Currah and Gary D. Prideaux

The Pragmatic Function of wa in Japanese................. 325

Jila Ghomeshi

The Semantics of the Bengali Verb fela .................. 337

Laurie Zaring

On Prepositions and Case-Marking in French $\ldots \ldots \ldots \ldots \ldots \ldots \ldots$

Reviews/Comptes rendus

J.K. Chambers: Davis, Statistics in Dialectology ............... 379

Steven N. Dworkin: Malkiel, Diachronic Problems in Phonosymbolism ....... 382

Donald G. Frantz: Steele, Agreement and Anti-Agreement............. 385

Brian Gill: Steele, ed., Meaning-Text Theory ................... 387

L.G. Kelly: Bubenik, Hellenistic and Roman Greece as a Sociolinguistic Area . 389

Brian King: Luke, Utterance Particles in Cantonese Conversation ......... 393

Darlene LaCharité: Paradis and Prunet, eds., Phonetics and Phonology:

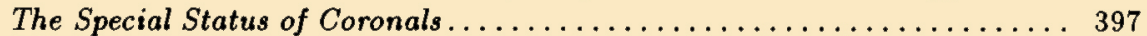

Bert Peeters: Guillaume, Esquisse d'une grammaire descriptive de la langue

française II; Greidanus, Les constructions verbales en français parlé;

Corrigan, Eckman, and Noonan, eds., Linguistic Categorization;

Marxgut, Der französische Sozialwortschatz im 17. Jahrhundert;

Anderson and Owens, eds., Propositional Attitudes ................ 400

Marc Picard: Baldi, ed., Linguistic Change and Reconstruction Methodology. . . 415

Paul Proulx: Harrison, Signs, Songs, and Memory in the Andes . . . . . . . 419

Rajendra Singh: Koerner, Practicing Linguistic Historiography . . . . . . . 424

Heidi Waltz: Bammesberger, Die Morphologie des urgermanischen Nomens . . 428

Helmut Zobl: Matthews and Demopoulos, eds., Learnability and

Linguistic Theory ........................... 430

Books Received $/$ Livres reçus $\ldots \ldots \ldots \ldots \ldots \ldots \ldots \ldots \ldots \ldots \ldots \ldots \ldots$

Canadian Journal of Linguistics

Revue canadienne de Linguistique

36(4) : 325-436

Dec./dép. 1991 